\title{
Social Impact Assessment of the Biogas Production through Biomass for Bansuanmiang School under the Smart School Project
}

\author{
Prapita Thanarak ${ }^{1, a^{*}}$ \\ ${ }^{1}$ School of Renewable Energy Technology, Naresuan University, Phitsanulok, 65000, Thailand \\ aprapitat@nu.ac.th
}

\section{Keywords: Social Return on Investment; Biogas; Smart School}

\begin{abstract}
Small scale biogas plants were established at existing lands of seven small size schools at three provinces in lower northern part of Thailand. The successful experience of a small school at Khaonoi was used to implement this project, where food waste and animal dung have been used to produce biogas which replaced LPG used to cook lunch for students. After the successful implementation of project, these sites were used to train/ demonstrate the concerned from about 1,717 small size schools in target areas. The proposed project is conceived to open new venues in promoting and implementing Renewable Energy Technology. The establishment of university (R\&D) to school/ community(end user) relationship is very important aspect of the idea, which not only be perfect to implement the project smoothly but will create new ways to collect feedback and solve the issues immediately. Project sites being distributive in nature and community participated will act as a RE promotion hubs. The technology used is simple and all the materials involved are local. The project though has comparatively lower direct financial benefits, but has tremendous social,environmental and health related benefits. The reduction of $\mathrm{CO}_{2}$ and other GHG will not only be beneficial locally but will contribute in achieving the globally fixed targets. Community participation will be an added benefit to promote and expand the RE technologies among the masses over wide areas. The successful operation will be a strong message for visitors and the local community connected through their children with the school and hence project. The university level R\&D will get a way out for direct implementation and technology will be used for the betterment of communities and will participate in global efforts to reduce $\mathrm{CO}_{2}$ emissions as well.
\end{abstract}

\section{Introduction}

In Thailand, the school lunch project has limited budget about 13-20 Thai Baht per student per day. A reasonable amount (around 5-10\%) from this budget goes for LPG purchasing. The prospective increase in LPG price will further reduce the quality and quantity of student's lunch. The objective of this project was to use the food and agriculture waste and animal dung to generate biogas energy for school lunch project. The saving in LPG usage will contribute in improvement of food quality and quantity in small size school. There are 32,879 such schools running under Office of the Basic Education Commission (OBEC), out of which 10,877 schools have less than 120 children thus having limited budget as its calculation bases on number of students. The school is free from LPG and can be designated as "Smart School". From the seven schools in three provinces were selected for system installation. Following are the selected schools; Watthamuenram school (Phitsanulok) Bansadao school (Phitsanulok), Bannamthongnoi school (Phitsanulok) Bansuanmiang school (Phitsanulok) Bannongkula school (Phitsanulok) Bansumen school (Sukhothai) and Anubankhonglan school (Kamphaengphet). There are no similar projects in the schools in lower northern region, however some schools in the capital city of Thailand and some adjacent provinces have plants which use organic waste. The promotional project of biogas production in 100 Schools was carried out in year 2008. The project was executed in collaboration with Department of Alternative Energy Development and Efficiency (DEDE), Ministry of Energy and Bangkok Metropolitan Administration. Organic waste in the school was collected, digested and biogas and fertilizer were produced. In 2011, project was expanded to 1,400 local administration offices, education institutes, hospitals and other organizations belonging to Ministry of Defense. The current 
project has a potential to expand in all regions of the country as the environmental and social conditions are same. For the smart school project, the School of Renewable Energy Technology (SERT) organized events of training and demonstration for people from target areas and the presence of concerned departments and politicians will be ensured to promote the technology and expand the implementation. However, the people raise the questions about how the impact and value of the project. This paper applied the Social Impact Assessment (SIA) and Social Return on Investment (SROI) as a tool help us to communicate better the project impact to the public. With the theory of change that if there was the biogas system installed at the school, the students will have a better environment, the school will reduce LPG consumption and there are widespread use of biogas in the community around the school.

\section{Methodology}

SIA and SROI is a framework for measuring and accounting for this much broader concept of value; it seeks to reduce inequality and environmental degradation and improve wellbeing by incorporating social, environmental and economic costs and benefits. SROI is about value, rather than money. Money is simply a common unit and as such is a useful and widely accepted way of conveying value [1]. SROI can helping the project target appropriate resources at managing unexpected outcomes, both positive and negative. This paper presented the SROI of Bansuanmiang school which located in Chattrakan district, Phitsanulok province. The methodology of this study was to establishing scope and identifying stakeholders, mapping outcomes, evidencing outcomes and giving them a value, establishing impact and calculating the SROI.

The techniques for primary data collection included one-to-one interviews and focus group. The impact value chain was presented at following table 1. Deadweight was calculated for LPG price may decrease during January 2015- May 2016 as a control fuel of the Royal Thai government and report of Industrial product price [3]. The stakeholders mentioned that there were no displacement and $100 \%$ attribution from this project. Drop-off is usually calculated by deducting a fixed percentage from remaining level of outcomes at the end of each year. However, this biogas system has been operated for 8 months from October 2015- May 2016; the drop-off was calculated for school holidays only. Financial proxy for the monetization was collected from the stakeholders and related researches and calculated with following equation (1).

$$
\begin{aligned}
\text { Present Value } & =\frac{\text { Value of Impact in Year } 1}{(1+r)}+\frac{\text { Value of Impact in Year } 2}{(1+r)^{2}}+\cdots \\
& +\frac{\text { Value of Impact in Year } n}{(1+r)^{n}}
\end{aligned}
$$

Where $\quad r=$ Coupon rates of floating rate bonds from Bank of Thailand (1.53) [2]

$n=$ Project Life time 1 year

$$
\text { SROI ratio }=\text { Present Value / Value of inputs }
$$

\begin{tabular}{|c|c|c|c|}
\hline Inputs & Activities & Outputs & Outcomes \\
\hline $\begin{array}{l}\text { Project investment for } \\
\text { this school }\end{array}$ & $\begin{array}{l}\text { Training on installation } \\
\text { and operation }\end{array}$ & $\begin{array}{l}\text { Savings in LPG } \\
\text { purchasing }\end{array}$ & $\begin{array}{l}\text { Reduce LPG } \\
\text { consumption }\end{array}$ \\
\hline $\begin{array}{l}\text { Investment cost of } \\
\text { Biogas system }\end{array}$ & $\begin{array}{l}\text { Monitoring on the } \\
\text { operation and } \\
\text { maintenance }\end{array}$ & $\begin{array}{l}\text { Amount of LPG } \\
\text { consumption } \\
\text { Level of } \mathrm{CO}_{2} \text { emissions } \\
\text { from less LPG } \\
\text { consumption }\end{array}$ & Safe environment \\
\hline $\begin{array}{l}\text { Time spent engaged in } \\
\text { these activities of } \\
\text { stakeholders }\end{array}$ & & $\begin{array}{l}\text { Number of community } \\
\text { applied/utilized the } \\
\text { biogas system }\end{array}$ & $\begin{array}{l}\text { Transfer technology to } \\
\text { the community }\end{array}$ \\
\hline
\end{tabular}

Table 1 Impact value chain of biogas production through biomass for Bansuanmiang school 


\section{Results and Discussion}

Project Technical viability. The biogas production through organic wastes and animal dung is a time tested technology. The climatic conditions in Thailand are supportive to the technology and a successful example of Khaonoi is in hand. The community and schools together have sufficient resources for organic input. The plants can be constructed with $100 \%$ local materials and can be operated and maintained easily. The materials and appliances are simple and familiar. A biogas plant with a 2cubic meter capacity requires only 3-5 cows (or buffaloes/pigs) for biogas production. There are 4 units for each school. For each unit, $1-3 \mathrm{~kg}$ of food waste or animal dung, every 1-2 day in a ratio of 1:1 (organic waste: water) is needed. Total ingredients =water+organic waste $(3 \mathrm{~kg}+3 \mathrm{~kg})$ $\mathrm{x} 15$ days $=90 \mathrm{~kg}$. At Bansuanmiang school, the organic matter available for biogas production was $3 \mathrm{kgs}$ of chicken dung and $5 \mathrm{kgs}$ food waste per day with $32 \mathrm{kgs}$ cow dung per week. Amount of the organic fertilizer (as a fermentation product) available was $45 \mathrm{~L} / \mathrm{month}$. By mixing the organic fertilizer with clean water in a ratio of 1:20, about $900 \mathrm{~L}$ of an organic liquid fertilizer can be collected each month for spraying. Basic maintenance is to clean sediment releasing pipe at least every 3 years to prevent pipe blockage. Regular checking for gas leakage and cleaning was done.

Management model and economic sustainability. This is a community participation project so no revenue generated. As the inputs supplied by the community and schools jointly so long term sustainability will be possible. The concerned school is the owner of the assets and the head of school monitor the O\&M and coordinate with SERT and community for sustainable successful operation of the plant. There is no new land requirements as the plants was constructed on the existing land available with the school. About $30-60 \mathrm{kgs}$ of LPG is used for each school lunch project. Total budget per student per day is about 13 Thai Baht. Beside the saving of LPG and production of fertilizer the reduction in GHG was possible and the success was a provocation for communities around to built their own biogas plants. Biogas plants of this size require very little maintenance and the inputs are freely available for sustained operation, which will lead to a successful project in long term. Project contributed in capacity building of community and school as well. SERT can extend its experience at Khaonoi for active community participation and the community organizations can be formed to ensure the project sustainability.

Environmental benefits. At least $30 \mathrm{kgs}$ of LPG is normally consumed by each school per month, hence about 360 liters per year per school. The efficiency factor being the non-OECD country is assumed as $80 \%$. Thus, the PEI is 288 liters/year for each school. The reduction of primary fossil energy use for one school with 4 units of biogas comes out to be 0.61 cubic meter per day. The carbondioxide emission reduction from biogas generation of this project is $111 \mathrm{kgCO} 2$ per year. Besides that all the resources proposed to use in the project are natural and renewable. There are no risks of negative ecological side effects as the project neither involves any major diversion or disturbance to the water flows, nor any major destruction of flora $\&$ fauna. The land use is very limited and practically does not have any effect on environment. Average water consumption of about 8 liters/day per system is expected with no interference in food supply. Moreover there are no negative health impacts rather there will be positive health effect due to improved waste management through biological means and reduction in unpleasant odor.

Social context and impact. The small schools being mostly located in villages always get reasonable support from the community. Thailand has a culture of community participation and mutual cooperation. The required input for such type of projects is abundantly available being an agricultural country. At present many biomass projects are operational here and every additional day of their successful operation inspires other to participate in implementing the clean and safe technologies. There may not be direct employment creation in the area but the capacity building of school staff, students or villagers who participate in the project may lead to their earning. Development of more community projects after the successful demonstration at schools can trigger a new trend and thus will not only create the employment but many other economic activities like construction of tanks, support materials etc. Also, the food waste or animal dung after generating biogas will be converted to useful fertilizer. It will improve the sanitation and community will get 
equally efficient fertilizer too. The improved sanitation will not only help in better environment but the children will also get improved food both in quality and quantity. It will also help keeping the environment of school and peripheral areas clean and healthy. Project activities facilitated numerous community groups to work together and enhance mutual cooperation. It will also help in building a close coordination among researchers, implementers and end users. The ministry of energy being important stake holder will get in depth view of community trends and potentials, hence making them able to conceive new projects in alternate energy field. For the purpose of R\&D and technology improvements the end user's feedback especially in the long term operation will be of prime importance. Which in turn will contribute in the development of renewable energy technologies.

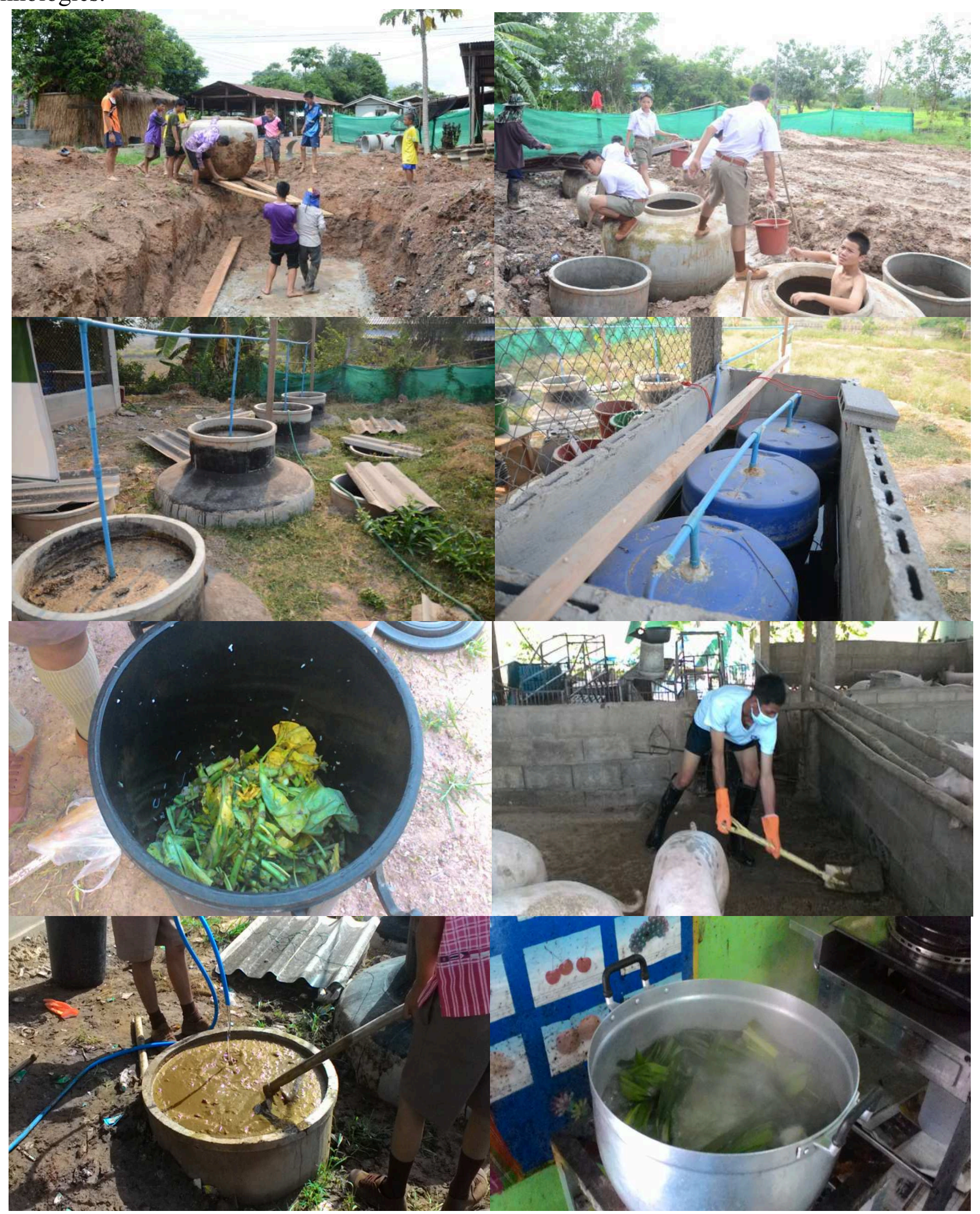

Fig.1 Highlight activities at Bansuanmiang School 


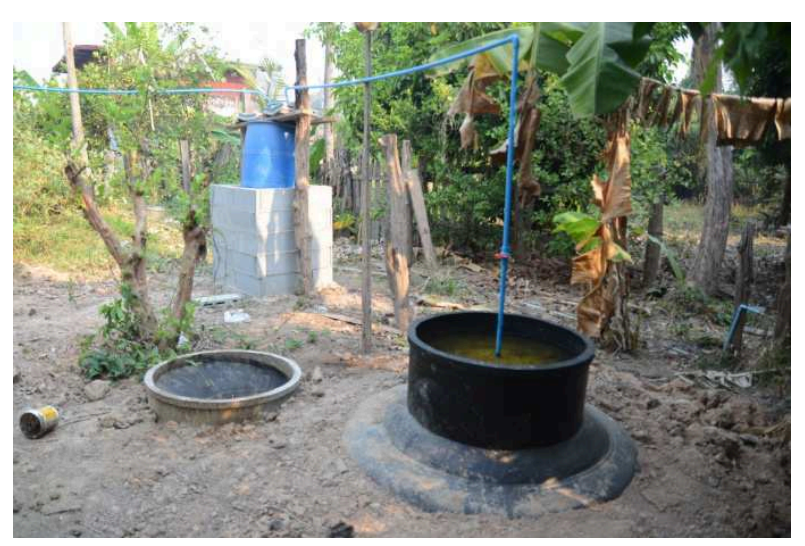

Fig. 2 Biogas utilization in the community

\section{Summary}

SIA and SROI focus and emphasizes on the need to measure value from the bottom up, including the perspective of different stakeholders. Hence, there is a novelty issue for biogas project as most previous studies about biogas were focused on technical, economic, environmental and policy issues [4-15]. The SROI value more than 1 may not presents the high or acceptable benefits of the project like benefit cost ratio of cost benefit analysis. However, for this tool of assessment, other issues have to be integrated consider in helping project plan for the social sustainability.

\section{Acknowledgements}

This study is a part of the "Smart school in Lower Northern Region of Thailand generating biogas through biomass" project which financial supported by Wuppertal Institute for Climate, Environment and Energy (WISIONS), Germany and School of Renewable Energy Technology (SERT), Naresuan University, Thaliand.

\section{References}

[1] Cabinet Office, A guide to Social Return on Investment, Society Media, UK, 2009.

[2] Information on https://www.bot.or.th

[3] Information on http://www2.bot.or.th/statistics/ReportPage.aspx?reportID=90\&language=th

[4] Prapita Thanarak, Supply chain management of agricultural waste for biomass utilization and $\mathrm{CO}_{2}$ emission reduction in the lower northern region of Thailand, Energy Procedia, 14 (2012) 843848.

[5] S. Keyuraphan, P. Thanarak, N. Ketjoy and W. Rakwichian, Subsidy schemes of renewable energy policy for electricity generation in Thailand, Procedia Engineering, 32 (2012) 440-448.

[6] Sayan Chakrabarty, F.I.M. Muktadir Boksh and Arpita Chakraborty, Economic viability of biogas and green self-employment opportunities, Renewable and Sustainable Energy Reviews, 28 (2013) 757-766.

[7] Bambang Sugiyono, Agus Purwono Suyanta and Rahbini, Biogas digester as an alternative energy strategy in the marginal villages in Indonesia, Energy Procedia, 32 (2013) 136-144.

[8] Bettina Bluemling, Arthur P.J.Mol and Qin Tu, The social organization of agricultural biogas production and use, Energy Policy, 63 (2013) 10-17. 
[9] Sri Atmaja P. Rosyidi, Tjasa Bole-Rentel, Surya Budi Lesmana and Jazaul Ikhsan, Lessons learnt from the energy needs assessment carried out for the biogas program for rural development in Yogyakarta, Indonesia, Procedia Environmental Sciences, 20 (2014) 20-29.

[10] Andrew Whiting and Adisa Azapagic, Life cycle environmental impacts of generating electricity and heat from biogas produced by anaerobic digestion, Energy, 70 (2014) 181-193.

[11] Sara Evangelisti, Paola Lettieri, Domenico Borello and Roland Clift, Life cycle assessment of energy from waste via anaerobic digestion: A UK case study, Waste Management, 34 (2014) 226237.

[12] Peter Nabusiu Walekhwa, Drake Lars and Johnny Mugisha, Economic viability of biogas energy production from family-sized digesters in Uganda, Biomass and Bioenergy, 70 (2014) 26-39.

[13] Ratih Novi Listyawati, Christia Meidiana and Mustika Anggraeni, Evaluation of energy selfsufficient village by means of emergy indices, Procedia Environmental Sciences, 20 (2014) 30-39.

[14] Yiying Jin, Ting Chen, Xin Chen and Zhixin Yu, Life-cycle assessment of energy consumption and environmental impact of an integrated food waste-based biogas plant, Applied Energy, 151 (2015) 227-236.

[15] I. Gusti Ayu Nyoman Budiasih, Social and environment accounting practices at the time of the ancient Bali, Procedia - Social and Behavioral Sciences, 219 (2016) 145-151.

[16] Kok Sin Woon, Irene M.C.Lo, Sam L.H.Chiu and Dickson Y.S.Yan, Environmental assessment of food waste valorization in producing biogas for various types of energy use based on LCA approach, Waste Management, 50 (2016) 290-299.

[17] David Styles, Eduardo Mesa Dominguez and Dave Chadwick, Environmental balance of the UK biogas sector: An evaluation by consequential life cycle assessment, Science of the Total Environment, 560-561 (2016) 241-253.

[18] Krittaphas Mongkoldhumrongkul and Prapita Thanarak, Key factors of community based biomass power plant establishment, Applied Mechanics and Materials, 839 (2016) 75-80.

[19] Changbo Wang, Yaoqi Zhang, Lixiao Zhang and Mingyue Pang, Alternative policies to subsidize rural household biogas digesters, Energy Policy, 93 (2016) 187-195.

[20] Ola Eriksson, Mattias Bisaillon, Marten Haraldsson and Johan Sundberg, Enhancement of biogas productin from food waste and sewage sludge-environmental and economic life cycle performance, Journal of Environmental Management, 175 (2016) 33-39. 